\title{
Łukasz Górski
}

Uniwersytet Mikołaja Kopernika, Toruń

lukasz.gorski@gmail.com

\section{Technology vis-à-vis law. Research \\ in the area of law representation}

DOI: http://dx.doi.org/10.12775/SIT.2016.003

\section{Introduction}

In one of his papers, Richard Posner expressed the view that the autonomy of law is declining and it is no longer a discipline that could be entrusted exclusively to people trained and skilled solely in the art of law ${ }^{1}$. His line of thought follows, to some extent, the famous century-old words of Oliver Wendell Holmes, that „[f]or the rational study of the law the black-letter man may be the man of the present, but the man of the future is the man of statistics and the master of economics"2.

Yet, the methodological debate on the autonomy is law is a dated one and seems unsettled up to this time. Some authors have pointed out, for example, that the economy itself is a discipline developing within its own limitations, only recently incorporating theories pertaining to human irrationality. As the law

1 R. Posner, The Decline of Law as an Autonomous Discipline: 1962-1987, „Harvard Law Review” 1987, vol. 4, p. 762, http://dx.doi.org/10.2307/1341093.

2 O.W. Holmes, The Path of the Law, „Harvard Law Review” 1987, vol. 10, p. 469, http://dx.doi.org/10.2307/1322028. 
and economics is even less advanced than economical sciences, economical analysis in law may be of little practicality ${ }^{3}$. Bartosz Brożek and Jerzy Stelmach present a number of theoretical positions regarding the methodological autonomy of law, ranging from complete lack of (scientific) methods used in law through methodological heteronomy (i.e. a position that jurisprudence is scientific as long as it incorporates methods from other, better-developed sciences) to a complete methodological autonomy of jurisprudence ${ }^{4}$.

However, we are not going to settle the debate (as this would be an overly-ambitious aim), nor to give a detailed report on it. Rather, we would like to take Richard Posner's remark as a starting point for discussion on the influence of other fields of thought on law. While Richard Posner in his paper stresses the connection between law and economy and, to a lesser degree, law and philosophy, it should be noted that legal doctrine has started to integrate results from a number of other disciplines. Surprisingly, legal research was already influenced by results from cognitive sciences ${ }^{5}$, game theory ${ }^{6}$ or evolutionary theories ${ }^{7}$.

Views of decline of law autonomy are resonated and further developed in Richard Susskind's works. Grounded both in academia and in professional legal counseling business, the author predicts the market of professional legal advice is going to witness radical changes. He mentions two economically-inclined factors: „more for less" challenge and liberalization of legal advice and one factor that is not immediately connected with economy: a technological change $^{8}$. The first factor is concerned with legal advice cost reduction $^{9}$, the second one with dehermetization of legal counseling

3 S.L. Schwarcz, Introduction: Is Law an Autonomous Discipline?, „Harvard Journal of Law and Public Policy" 1997, vol. 21, p. 85-86.

4 J. Stelmach, B. Brożek, Metody prawnicze, Kraków 2006, pp. 11-32.

5 B. Brożek, Granice interpretacji, Kraków 2014.

6 W. Załuski, Game Theory in Jurisprudence, Kraków 2013.

7 Idem, Evolutionary Theory and Legal Philosophy, Cheltenham 2009, http:// dx.doi.org/10.4337/9781781953075.

8 R. Susskind, Prawnicy przyszłości, Warszawa 2013.

9 Ibidem, p. 26. 
effecting in the creation of new structures and services in answer to "more-for-less" challenge ${ }^{10}$. However, the in-depth discussion of aforementioned phenomena is out of the scope of this paper.

The paper focuses on the technological change, the third phenomena mentioned by Richard Susskind. The author goes as far as to classify the developments in the area of information and communication technologies as "disruptive" 11 to the legal market. He describes no less than thirteen technological advances that are impacting the current landscape of professional legal service market and traditional workflow of legal service.

We will shift our attention to mainly one aspect of disruptive technologies: use of artificial intelligence methods for legal problems solving ${ }^{12}$. To an extent, our analysis will also be relevant to another aspect, i.e. the internalization of legal knowledge. In this respect, Susskind describes a vision of legal provisions that are incorporated in objects of everyday use (think of intelligent building monitoring various parameters in accordance with work safety regulations and raising an alarm in case of non-compliance; thus the lawyer role in compliance regulations monitoring is reduced ${ }^{13}$ ). As the internalization of legal norms is connected with their representation and reasoning, therefore it also falls under ambit of this paper.

We contribute by supplying an illustrative material for Richard Susskind's theses and by pointing out the research current pertaining to artificial intelligence development in the area of law. Moreover, some philosophical remarks will be made. As the general theory of law vis-à-vis of technology is currently lacking ${ }^{14}$, the

10 Ibidem, p. 26-32.

11 Ibidem, p. 68.

12 Other aspects of technological change mentioned by R. Susskind are as follows: automatic document processing, constant connectivity, electronic legal services market, e-learning, online legal advice, open-sourcing of legal services, closed legal communities, project and workflow management, online dispute resolution, intelligent search for legal issues, big data, cf. ibidem, pp. 67-78.

13 Ibidem, p. 75.

14 Cf. L.B. Moses, Why Have a Theory of Law and Technological Change?, „Minnesota Journal of Law, Science and Technology" 2007, vol. 2. 
presented analyses will be partially supported by the works of representatives of Science, Technology and Society Studies, an interdisciplinary field of research regarding the interaction between the technology and the society. In this paper we refrain from making any conclusive remarks regarding the future development of law due to the difficulties regarding the prediction of future technology developments and its interaction with social reality; as the famous quote concisely says, ,[p]rediction is very difficult, especially about the future" ${ }^{15}$. Any such remarks would have to be unfalsifiable and, at least to some extent, speculative.

\section{Technological determinism and its refutations}

We would like to refrain from making any remarks that may be regarded as supporting technological determinism (according to Bruce Bimber it is an intellectual stance that assumes that technological advancements shape the social practices with force similar to the laws of nature ${ }^{16}$ ). Contemporary analyses made on the ground of sociological studies pronounce the influence as more nuanced and reciprocal ${ }^{17}$. On the philosophical grounds, Luciano Floridi downplays technological determinism as well and goes as far as to call its death ${ }^{18}$. Yet, his mode of thinking still ascribes a pronounced role to technological advancements in the sphere of information technology, as „digital ICTs (information and communication technologies) are affecting our sense of self, how we relate to each other, and how we shape and interact with our world" 19 . According to Luciano Floridi, we are at the doorstep of revolution

15 Often (mis-)attributed to Niels Bohr, cf. A.K. Ellis, Teaching and Learning Elementary Social Studies, Pearson 1970, p. 431.

16 E. Bińczyk, Technonauka w społeczeństwie ryzyka, Toruń 2012, pp. 28-29.

17 Ibidem, p. 30.

18 L. Floridi, The Ethics of Information, Oxford 2013, p. 1, http://dx.doi. org/10.1093/acprof:oso/9780199641321.001.0001.

19 Idem, The Fourth Revolution: How the Infosphere is Reshaping Human Reality, Oxford 2014, p. VI. 
enabled by new ICT technologies, with „online” lives gaining on importance. He resorts to call humans by the neologism „inforgs”, i.e. informational organisms ${ }^{20}$. Such remarks echo those made by J. David Bolter three decades earlier. He noted that „the computers constantly [...] contribute [...] to a general redefinition of certain basic relationship: the relationship of science to technology, of knowledge to technical power, and, in the broadest sense, of mankind to the world of nature. This process [...] is not new. Technology has always exercised such an influence"21.

On the other hand, a number of authors assume a more critical position. Evgeny Morozov is exemplary in this respect, bashing, what he calls "technological solutionism” ${ }^{22}$. The following passage offers a concise summary of his position: „Once we realize that for the last hundred years or so virtually every generation has felt like it was on the edge of a technological revolution - be it the telegraph age, the radio age, the plastic age, the nuclear age, or the television age - maintaining the myth that our own period is unique and exceptional will hopefully become much harder"23. Luciano Floridi's claims were further refuted by John R. Searle. According to him, „When Floridi tells us that there is now a fourth revolution - an information revolution so that we all now live in the infosphere (like the biosphere), in a sea of information - the claim contains a confusion. The other three revolutions all identify features that are observer independent. Copernicus, Darwin, and Freud all proposed theories purporting to identify actual, observer-independent facts in the world: facts about the solar system, facts about human evolution, and facts about human unconsciousness" ${ }^{24}$. In the view of John R. Searle, Luciano Floridi's informational revolution is purely subjective one. Information is

\footnotetext{
20 Ibidem, p. 94.

${ }^{21}$ J. David Bolter, Turing's Man: Western Culture in the Computer Age, University of North Carolina Press 1984, p. 9.

22 Cf. E. Morozov, To Save Everything. Click Here, New York 2013.

23 Ibidem, p. 357.

24 J.R. Searle, What Your Computer Can't Know, „The New York Review of Books”, 9 October 2014, available: http://static.trogu.com/documents/articles/palgrave/ references/searle\%20What\%20Your\%20Computer\%20Can\%E2\%80\%99t\%20
} 
something we internalize, devoid of objective existence and therefore at least less important than e.g. Copernican one.

The debate on the importance and impact of information technologies is alive in the area of law as well. Frank H. Easterbrook resorts to colourful analogies to prove that his peers tend to ascribe too much of an importance to the development of technology. He resents the emergence of a very specific area of law dealing specifically with information technologies (i.e. „cyberlaw”, „IT law”). Along the lines of Evgeny Morozov's ways of thought he notices „that the best way to learn the law applicable to specialized endeavors is to study general rules. Lots of cases deal with sales of horses; others deal with people kicked by horses; still more deal with the licensing and racing of horses, or with the care veterinarians give to horses, or with prizes at horse shows. Any effort to collect these strands into a course on "The Law of the Horse" is doomed to be shallow and to miss unifying principles" 25 . The phrase "Law of the Horse” entered a public discourse for a moment and Frank H. Easterbrooks's received replies from a number of authors, including Lawrence Lessig. Lessig wholeheartedly disagreed with Easterbrook's position because "general point is about the limits on law as a regulator and about the techniques for escaping those limits" ${ }^{26}$.

Similarly, some authors argue that discussions concerning the (i) IT and ICT laws and (ii) information and communications technologies for lawyers are rather separated, yet developments in the areas of knowledge representation languages (KRL), ontologies, semantic networks and Natural Language Processing calls for integration of those two lines of thought. Discussions concerning, inter alia, Internet access, creation and protection of computer software, copyright and privacy cannot ignore technological factors. Similarly, technological developments needs to account for legal environment ${ }^{27}$.

Know\%20by\%20John\%20R.\%20Searle\%20\%7C\%20The\%20New\%20York\%20 Review\%20of\%20Books.pdf (access: 31.01.2016), p. 5.

25 F.H. Easterbrook, Cyberspace and the Law of the Horse, „The University of Chicago Legal Forum" 1996, p. 207.

26 L. Lessig, The Law of the Horse: What Cyberlaw Might Teach, „Harvard Law Review” 1999, vol. 113, p. 501.

27 W. Cyrul, J. Duda, J. Opiła, T. Pełech-Pilichowski, Informatyzacja tekstu prawa. Perspektywy zastosowania języków znacznikowych, Warszawa 2014, p. 12. 
Mireille Hildebrandt, borrowing language from the representatives of Science and Technology Studies, argues that law and its medium are closely interrelated. Modern law is already embedded in a specific technology, i.e. the written and printed script and, historically, has undergone transformation from oral form to written. Therefore "[s]peaking the law in an oral tradition was performed by a court that practiced mediation, requiring the cooperation of the parties that were basically peers of the judge. Written law created new hierarchies and segmentations in society, not necessarily beneficial for the illiterate majority. The transition from an oral to a written legal tradition (and from a hand-written to a printing press legal tradition) has transformed law"28. Similarly, according to Hildebrandt, technological innovations call for the digitalization and technological embodiment of law. Here, she explicitly echoes the position of Peter-Paul Verbeek. In his well-known essay he stated that technology mediates human action ${ }^{29}$. In other words, material objects implicitly posses scripts that guide action ${ }^{30}$. Surprisingly, the same position was put forth by Lawrence Lessig in his reply to Frank H. Easterbrook. Without recalling Peter-Paul Verbeek works explicitily, he acknowledges the mediating role of material objects, for example, ,[t]hat a highway divides two neighborhoods limits the extent to which the neighborhoods integrate" ${ }^{31}$. Obviously, technological internalization of legal norms, in line with Richard Susskind's vision, would make mediating power even more pronounced. How can that be achieved and what is needed to achieve this aim?

28 M. Hildebrandt, A Vision of Ambient Law, in: Regulating Technologies: Legal Futures, Regulatory Frames and Technological Fixes, eds. R. Brownsword, K. Yeung, Oxford 2008, pp. 179-180, http://dx.doi.org/10.5040/9781472564559. ch-008.

29 P. Verbeek, Materializing Morality. Design Ethics and Technological Mediation, „Science, Technology and Human Values” 2006, vol. 31, available: https://www. utwente.nl/bms/wijsb/organization/verbeek/materializingmorality.pdf (access: 31.01.2016), http://dx.doi.org/10.1177/0162243905285847.

30 Ibidem.

31 L. Lessig, op.cit., p. 507. 


\section{AI and law movement and its research directions}

Notwithstanding the debates regarding the status of information technology vis-à-vis law, it should be noted that vast body of research has already been devoted to this problem, mainly in AI and Law research field. As a subfield of artificial intelligence research, it integrated methods of both formal and social sciences and integrated researchers stemming from, inter alia, computer science, logic, linguistics, law and philosophy. As for the research aim, ,[i]n the best of AI tradition, AI and Law seeks to provide concrete computational means to challenge assumptions and provide grounding on many questions of jurisprudence"32.

Law is characterized by a number of features that are especially challenging for the artificial intelligence researcher, making it an ideal subject for investigation ${ }^{33}$. Its features concern, inter alia, a vast body of sources, variety of task orientations (advocacy, adjudication, advising, planning and drafting). Its concepts are open-textured and a number of competing, reasonably-justified and evolving answers could be given to exemplary, non-trivial problems ${ }^{34}$. On the other hand law can be considered a highly reflective discipline that is constantly concerned with its methods and missions. Therefore, „[i]n providing computational models that address how one thinks in legal matters, AI and Law seeks to provide an alternative grounding for the analyses of jurisprudential scholars and new tools for investigating their ideas. Models of argument and case similarity are good examples of how AI and Law research can flesh out skeletal descriptions developed by legal scholars, and can provide a way to explore them to see how they work and how well they work. AI and Law has been described by

\footnotetext{
32 E.L. Rissland, K. Ashley, R. Loui, AI and Law: A fruitful synergy, „Artificial Intelligence" 2003, vol. 1-2, p. 2, http://dx.doi.org/10.1016/S0004-3702(03)00122-X.

33 Cf. Ibidem.

34 The following enumeration is adapted from: ibidem, pp. 2-5.
} 
the late Donald Berman, one of the field's founders and a distinguished professor of law, as "a new analytical jurisprudence»". Richard Susskind suggests that cooperation should also facilitate the other direction of influence: ,jurisprudence can and ought to supply the models of law and legal reasoning that are required for computerized implementation in the process of building all expert systems in law" ${ }^{35}$. Therefore law and artificial intelligence research offer a "fruitful synergy”; challenges and insights from one of those disciplines can contribute to the development of other ${ }^{36}$.

There are four main areas of interest of this area of inquiry: (i) application of computational methods to legal reasoning, (ii) formal representation of legal norms, addressees of those norms and legal institutions as well as the interactions of legal subjects (within multi-agent systems), (iii) research regarding the application of advanced technologies with law as an illustrative material and (iv) application of advanced information technologies for solving problems arising during legal reasonings ${ }^{37}$.

Not all authors completely agree with the idea of „fruitful synergy” though. Although Richard Susskind still argues that „all expert systems must conform to some jurisprudential theory because all expert systems in law necessarily make assumptions about the nature of law and legal reasoning. To be more specific, all expert systems must embody theories of legal knowledge, legal science, the structure of rules, the individuation of laws, legal systems and sub-systems, legal reasoning, and of logic and the law (as well perhaps as elements of a semantic theory, a sociology, and a psychology of law), theories that must all themselves rest on more basic philosophical foundations"38, James Popple refutes. By assuming the pragmatic position, he compares the situation of an expert system to that of practicing lawyer. Even though she

\footnotetext{
35 R. Susskind, Expert Systems in Law: A Jurisprudential Inquiry, Oxford 1988, p. 20.

36 E.L. Rissland, K.D. Ashley, R.P. Loui, op.cit., pp. 1-15.

37 M. Araszkiewicz, Poradnictwo prawne $i$ obywatelskie a nowe technologie, http://www.inpris.pl/fileadmin/user_upload/documents/pomoc_prawna/Poradnictwo_a_nowe_technologie.pdf (access: 29.01.2016), p. 2.

38 J. Popple, A pragmatic legal expert system, Dartmouth 1996, p. 6.
} 
usually posses some mental model of the law, in most cases it does not rely on some vocalized legal theory, but might have been acquired tacitly and constructed while performing professional legal tasks ${ }^{39}$. Notwithstanding this position, it can be noted that researchers in the area of AI and Law in fact keep discussing with legal theorists and include a number of them ${ }^{40}$.

The problem of law representation and reasoning is a difficult one and lacks simple solutions. For example, the straightforward answer to question of what do lawyers know with lawyers knows the law (i.e. particular legal provisions stated in particular source of law) has proven to be lacking ${ }^{41}$. One of the first legal expert systems (British Nationality Act System of Imperial College) was concerned with the declarative representation of knowledge pertaining to the British Nationality Act. It used a simple transformation of legal provisions from their textual representation to a computer-understandable one (technically, the law was represented as a set of Horn clauses). The representation of law was not concerned with broader, contextual knowledge regarding the problems pertaining to the nationality ${ }^{42}$. While successful in this case, such approach has proven to be unsusceptible for generalization to other acts and areas of law ${ }^{43}$. The lack of contextual knowledge has proven to yield wrong results in a number of other applications, including trade secrets law $^{44}$. Therefore, further research focused, apart from the development of pure rule-based reasoners (RBR) to the projects involving case-based ones (CBRs) and hybrid solutions. A research into ways of representing the semantically-enriched legal knowledge also continues, with the exemplary implementations of LKIF language ${ }^{45}$.

\footnotetext{
39 Ibidem.

40 E.L. Rissland, K.D. Ashley, R.P. Loui, op.cit.

${ }^{41}$ T. Bench-Capon, What Makes a System a Legal Expert?, in: Legal Knowledge Information Systems, JURIX 2012: The Twenty-Fifth Annual Conference, ed. B. Schafer, Amsterdam 2010, p. 1-3.

42 W. Cyrul, J. Duda, J. Opiła, T. Pełech-Pilichowski, op.cit., p. 22.

43 T. Bench-Capon, op.cit., p. 1-3.

44 W. Cyrul, J. Duda, J. Opiła, T. Pełech-Pilichowski, op.cit., p. 22.

45 Ibidem, p. 23.
} 


\section{Conclusion}

We have developed Susskind's theses by presenting them in broader social and philosophical context. Some of technical results regarding the representation of legal knowledge was also referenced. However, we have purposely refrained from giving a detailed analysis and description of technical results, settling down on giving a number of terms that can be used for further reference (CBRs, RBRs, LKIF). A number of other publications can be consulted for details on other projects, including the ones the authors of this paper were developing ${ }^{46}$.

\section{STRESZCZENIE}

Technologia a prawo.

Badania nad systemami reprezentacji prawa

W opracowaniu rozwinięto tezę Richarda Susskinda o rewolucyjnej roli technologii informacyjnej w prawie i o potencjale badań nad sztuczną inteligencją $\mathrm{w}$ tym zakresie. $\mathrm{W}$ tym celu zaprezentowane zostały niektóre argumenty dotyczące roli technologii w prawie oraz zaprezentowane kierunki badawcze podejmowane w ramach ruch $\mathrm{AI}$ and Law.

Słowa kluczowe: AI and Law; sztuczna inteligencja; system ekspertowy; społeczeństwo a technologia

\section{SUMMARY}

Technology vis-à-vis law. Research in the area of law representation

The paper develops Richard Susskind's theses on the disruptive role of IT in law and the potential effects on AI research in this area. In pursue of

\footnotetext{
46 Cf. S. Ramakrishna, Ł. Górski, A. Paschke, The Role of Pragmatics in Legal Norm Representation, http://arxiv.org/pdf/1507.02086.pdf (access: 31.01.2016), S. Ramakrishna, Ł. Górski, A. Paschke, KR4IPLaw Judgment Miner - Case-Law Mining for Legal Norm Annotation, „Lecture Notes in Artificial Intelligence” (in press).
} 
this aim some arguments regarding the importance of technology in law are presented as well as the research directions undertaken in the AI and Law research field.

Keywords: AI and Law; artificial intelligence; expert system; society and technology

\section{BIBILIOGRAPHY}

Araszkiewicz M., Poradnictwo prawne i obywatelskie a nowe technologie, http://www.inpris.pl/fileadmin/user_upload/documents/pomoc_ prawna/Poradnictwo_a_nowe_technologie.pdf (access: 29.01.2016).

Bench-Capon T., What Makes a System a Legal Expert?, in: Legal Knowledge Information Systems, JURIX 2012: The Twenty-Fifth Annual

Conference, ed. B. Schafer, Amsterdam 2010.

Bińczyk E., Technonauka w społeczeństwie ryzyka, Torun 2012.

Brożek B., Granice interpretacji, Kraków 2014.

Cyrul W., Duda J., Opiła J., Pełech-Pilichowski T., Informatyzacja tekstu prawa. Perspektywy zastosowania języków znacznikowych, Warszawa 2014.

David Bolter J., Turing's Man: Western Culture in the Computer Age, University of North Carolina Press 1984.

Easterbrook F.H., Cyberspace and the Law of the Horse, „The University of Chicago Legal Forum” 1996.

Ellis A.K., Teaching and Learning Elementary Social Studies, Pearson 1970.

Floridi L., The Ethics of Information, Oxford 2013, http://dx.doi. org/10.1093/acprof:oso/9780199641321.001.0001.

Floridi L., The Fourth Revolution: How the Infosphere is Reshaping Human Reality, Oxford 2014.

Hildebrandt M., A Vision of Ambient Law, in: Regulating Technologies: LegalFutures, RegulatoryFramesandTechnologicalFixes, eds.R.Brownsword, K. Yeung, Oxford 2008, http://dx.doi.org/10.5040/9781472564559. ch-008.

Holmes O.W., The Path of the Law, „Harvard Law Review” 1987, vol. 10, p. 469, http://dx.doi.org/10.2307/1322028.

Lessig L., The Law of the Horse: What Cyberlaw Might Teach, „Harvard Law Review” 1999, vol. 113.

Morozov E., To Save Everything. Click Here, New York 2013.

Popple J., A pragmatic legal expert system, Dartmouth 1996.

Posner R., The Decline of Law as an Autonomous Discipline: 1962-1987, „HarvardLaw Review” 1987, vol.4, http://dx.doi.org/10.2307/1341093. 
Ramakrishna S., Górski Ł., Paschke A., KR4IPLaw Judgment Miner- Case-Law Mining for Legal Norm Annotation, „Lecture Notes in Artificial Intelligence" (in press).

Ramakrishna S., Górski Ł., Paschke A., The Role of Pragmatics in Legal Norm Representation, http://arxiv.org/pdf/1507.02086.pdf (access: 31.01.2016).

Rissland E.L., Ashley K., Loui R., AI and Law: A fruitful synergy, „Artificial Intelligence" 2003, vol. 1-2, http://dx.doi.org/10.1016/ S0004-3702(03)00122-X.

Schwarcz S.L., Introduction: Is Law an Autonomous Discipline?, „Harvard Journal of Law and Public Policy" 1997, vol. 21.

Searle J.R., What Your Computer Can't Know, „The New York Review of Books”, 9 October 2014,available:http://static.trogu.com/documents / articles / palgrave/references /searle\%20What\%20Your\%20Computer\%20Can\%E2\%80\%99t\%20Know\%20by\%20John\%20R.\%20Searle\%20\%7C\%20The\%20New\%20York\%20Review\%20of\%20Books.pdf (access: 31.01.2016).

Stelmach J., Brożek B., Metody prawnicze, Kraków 2006.

Susskind R., Expert Systems in Law: A Jurisprudential Inquiry, Oxford 1988.

Susskind R., Prawnicy przyszłości, Warszawa 2013.

Verbeek P., Materializing Morality. Design Ethics and Technological Mediation, „Science, Technology and Human Values” 2006, vol. 31, available: https://www.utwente.nl/bms/wijsb/organization/verbeek/materializingmorality.pdf (access: 31.01.2016), http://dx.doi. org/10.1177/0162243905285847.

Załuski W., Evolutionary Theory and Legal Philosophy, Cheltenham 2009, http://dx.doi.org/10.4337/9781781953075.

Załuski W., Game Theory in Jurisprudence, Kraków 2013. 
